\title{
INDEXING AND ABSTRACTING
}

Etikonomi: Jurnal Ekonomi is accredited by Ministry of Research, Technology and Higher Education Republic of Indonesia No. 051/E/KPT/2017 Since December 4, 2017 (valid until December 2022)

Etikonomi: Jurnal Ekonomi has been covered (indexed and abstracted) by following indexing services:

- Emerging Source of Citation Index (ESCI) Web of Science

- Directory of Open Access Journal (DOAJ)

- Dimensions

- CrossRef

- Ebsco (Open Access Directory)

- Goggle Scholar

- Portal Garuda

- Indonesian Scientific Journal Database (ISJD)

- Moraref

- Indonesia OneSearch

- Bielefiedl Academic Search Engine (BASE)

- Open Archive Initiative (OAI)

- Open Access Library

- Academic Keys

- Open Academic Journal Index

- Research Bible

- Cite Factor

- Eurasian Scientific Journal Index

- SciLit

- Harvard Library

- University of Oxford

- Boston University Library

- Ghent University Library

- Leiden University Library

- Imperial College London Library

- Universia

- The University of Sheffield Library

- University of Saskatchewan Library

- Stanford University Library

- Scholar Steer

- Directory of Abstract Indexing for Journal

- Turkish Education Index

- Directory of Research Journal Indexing

- Journal Index 


\title{
COPYRIGHT TRANSFER AGREEMENT
}

Authors submitting a manuscript do so on the understanding that if accepted for publication, copyright of the article shall be assigned to Etikonomi: Jurnal Ekonomi as publisher of this journal.

Copyright encompasses exclusive rights to reproduce and deliver the article in all forms and media, including reprints, photographs, microfilms and any other similar reproductions, as well as translations. The reproduction of any part of this journal, its storage in databases and its transmission by any forms or media, such as electronic, electrostatic and mechanical copies, photocopies, recordings, magnetic media, etc., will be allowed only with a written permission from Etikonomi: Jurnal Ekonomi.

Etikonomi: Jurnal Ekonomi, Editors, and International Advisory Editorial Board make every effort to ensure that no wrong or misleading data, opinions or statements be published in the journal. In any way, the contents of the articles and advertisements published in Etikonomi: Jurnal Ekonomi are sole and exclusive responsibility of their respective authors and advertisers.

The copyright form should be filled with respect to article and be signed originally and sent to the Editorial Office in the form of original mail, or scanned document file (softcopy) to:

\author{
M. Adam Camubar \\ Editorial Office Etikonomi \\ Faculty of Economics and Business \\ Syarif Hidayatullah State Islamic University Jakarta \\ Jl Ibn. Taimiyah IV, Ciputat, South Tangerang, Banten, Indonesia -15412- \\ Phone (+6221) 7493318, Fax. (+6221) 7496006 \\ Website: www.journal.uinjkt.ac.id/index.php/etikonomi \\ Email: etikonomi@uinjkt.ac.id
}




\section{Copyright Transfer Agreement}

Name of Principal Authors:

Address of Principal Authors:

Tel/Fax:

E-mail:

Author(s) Name:

Manuscript Title:

Date Received:

1. I/We submit to the Etikonomi: Jurnal Ekonomi. I/We certify that the work reported here has not been published before and contains no materials the publication of which would violate any copyright or other personal or proprietary right of any person or entity.

2. I/We hereby agree to transfer to Etikonomi: Jurnal Ekonomi / Publisher for the copyright of the above - named manuscript.

3. I/We reserve the following: (1) All proprietary rights other than copyright such as patent rights. (2) The right to use all or part of this article in future works of our own such as in books and lectures. Print or Type Name and Title of Author.

Date:.

Signature

(When there is more than one author, only the first author that sign this copyright) 



\section{Etikonomi \\ Jurnal Ekonami}

\section{WRITING GUIDANCE FOR ETIKONOMI: JURNAL EKONOMI}

1. The manuscripts represent academic research in economics, business, and management studies.

2. Upon the publication of the manuscript, the author should provide a letter states that the manuscripts have never been, or under consideration to be, published in other journal publications.

3. Structure of the manuscripts

a. Title. The title should be short, clear, and informative, but does not exceed 9 words.

b. Author's names and institutions. The author's names should be accompanied by the author's institutions and email addresses, without any academic titles and/or job title.

c. Abstract and keywords. The abstract should be less than 150 words. The key words should be 2 to 5 phrases.

d. Introduction. This section explains the background of the study, and aims of the manuscripts. It should be written without numbers and/or pointers.

e. Method. This section describes the tools of analysis along with the data and their sources.

f. Result and Discussion. This section explains the results of the study. Data should be presented in Tables or Figures when feasible. There should be no duplication of data in Tables and Figures. The discussion should be consistent and should interpret the results clearly and concisely, and their significance. It also should supported to suitable literature. The discussion should show relevance between the result and the field of investigation and/ or hypotheses. The discussion also should compare the result with previous research.

g. Conclusions. This section concludes and provides policy implications, if any, of the study.

h. References. This section lists only the papers, books, or other types of publications referred in the manuscript. We suggest authors to use reference management software like EndNote, Mendeley, Zotero, etc., to prepare citations and the list of references.

4. The authors should provide an index of subject, namely the specific term in the manuscript. The authors should also provide the index of authors, namely the key authors of papers referred in the manuscript. Please write the family name followed by the given name.

5. Estimation result from a software package is not allowed to be directly presents in the paper. They should be presented in equations with the appropriate estimation results.

6. Table format should contain only heading and contents. Please provide the top and bottom lines, along with the line(s) that separate the heading and the contents. Example: 
Table 1. The Growth of Third Party Fund, Financing and Asset (Billion rupiah)

\begin{tabular}{lllllll}
\hline & 2012 & 2013 & 2014 & 2015 & 2016 & 2017 \\
\hline Fundraising & 52.271 & 76.036 & 115.415 & 147.512 & 174.018 & 186.608 \\
Financing & 46.886 & 68.181 & 102.655 & 147.505 & 179.284 & 187.886 \\
Asset & 66.090 & 97.519 & 145.467 & 195.018 & 229.557 & 244.197 \\
\hline
\end{tabular}

Source: Islamic banking statistics, Bank of Indonesia

7. The manuscript is prepared in a quarto paper, single-sided, and double-space format. A new paragraph should start 5 characters from the left margin, using 12-size, garamond font type.

8. The manuscript is written in proper English, either British or American English, but not the combination of both, except for special editions.

9. The top and bottom margins are 1 inch.

10. The title is written using capital letters of 14 font size, centre position.

11. Sub titles are written using capital letters, started from the left margin.

12. Sub of sub titles are written using capital letters only at the beginning of each word except for connecting words. They should be started from the left margin.

13. References should be those of the last ten years publication, unless they are key references.

14. Citation in the text body should be written using the family name and years of publication. Example:
a. Mareta (2018) concludes that there is an impact of ....
b. According to Kotler (2010), intra industry trade can be ...
c. Wagner (in McCain, 1990) states that ...
d. The definition of flypaper effect is ... (Wagner, 1976).

15. Tables and figures should be presented as follows:
a. The name of tables and figures should follow a numbering system (Arabic numbering system). The names of the tables and figures are on the top and bottom parts of the tables, respectively.
b. The tables and figures should provide the source of information, if any, at the bottom part of both.

16. References should be written in alphabetical order, without any number. They should be written using the following criteria:

a. For books, the format should follow the following example:

Al Arif, M. N. R. 2015. Pemasaran Stratejik Pada Asuransi Syariah. Jakarta: Gramata.

b. For papers that are part of a book, the format should follow the following example:

Bahl, R. 2000. How to Design a Fiscal Decentralization. in Sahid, Y. (eds.), Local Dynamics in an Era of Globalization, 25-26, London: Oxford University Press.

c. For journal/magazine papers, the format should follow the following example:

Mareta, B. M. (2018). The Impact of ASEAN-Korea Free Trade Agreements on Indonesian Export of Manufacturing Goods. Etikonomi, 17(2), 161-184. https://doi.org/10.15408/etk. v17i2.7342.

17. The manuscript in microsoft word should be sent to etikonomi@uinjkt.ac.id or through online submission at: http://journal.uinjkt.ac.id/index.php/etikonomi/user/register 
19. A brief CV that records full name, academic title, institution, telephone, fax and mobile number should accompany the manuscript.

20. The decision of the manuscript are:
a. Accepted, or
b. Accepted with minor revision, or
c. Accepted with major revision, or
d. Rejected.

20. Further information about the journal can be seen at http://journal.uinjkt.ac.id/index.php/ etikonomi 
